\title{
War, Time, and Military Videogames: Heterogeneities and critical potential
}

This article contributes to a small, but growing, scholarship on military videogames. Focusing, specifically, on diverse manifestations of temporality within these games, it demonstrates that this genre is both more diverse, and has greater critical potential, than is often recognised. The article begins with a brief overview of contemporary scholarship on temporality, war and global politics. A second section then identifies three different ways in which temporality features in military videogames: (i) as a horizon, or historical background, against which they are produced and consumed; (ii) as a dramatic setting around which games and their narratives are structured; and, (iii) as duration - which may be accelerated or decelerated experienced by those playing these games. These three instantiations of time are then investigated via a new typology of military videogames, ordered around: mainstream military shooters, critical military shooters, critical procedural military games, and civilian-centred military games. This typology enables us, first, to show the centrality of temporal assumptions, arguments and experiences to the ways in which war is made meaningful across these games. And, second, to demonstrate the significance of distinct productions and experiences of temporality for the critical potentiality thereof.

Keywords: videogames; war; militarism; military videogames; temporality; time; global politics.

\section{Introduction}

Military videogames matter. As of February 2016, the Call of Duty series alone had combined sales of over 250 million copies; its total revenues of over $\$ 15 \mathrm{bn}$ making it one of the world's largest popular entertainment franchises (Activision 2016). This, as Stahl (2006, 118) identifies, is no isolated case either, where 'September 11, 2001 and the ensuing wars in Afghanistan and Iraq ushered in a boom in sales of war-themed video games for the commercial market'. Yet, the importance of these games extends far beyond their economic successes. As argued below, they also contribute to making war meaningful for publics around the world who are distanced from any encounter with 'real' 
military combat. On top of this, militaries themselves are increasingly experimenting with the genre through the production of games (e.g. America's Army in the USA (2002ongoing) and Glorious Mission in China (2011-ongoing)) and the 'gamification' of recruitment (e.g. the 2009 'Start Thinking Soldier' campaign in the UK). ${ }^{1}$

As the influence of military games has expanded, however, so too has criticism of their intent and consequences. America's Army (funded by the US Department of Defence), for instance, has attracted considerable opposition because it facilitates the state and its military targeting children (Power 2007, 281). Broader concerns, though, also exist, with commercially produced games standing accused of perpetuating racial othering and promoting 'recreational violence' (e.g. Šisler 2008). After years of neglect, scholars interested in conflict, militarism, and related dynamics have also begun paying attention to this cultural form (e.g. Höglund 2008; Huntemann and Payne 2009; Robinson 2012; Schulzke 2013), building on, and moving debate beyond, a number of early pioneering explorations on the simulated, net-centric nature of contemporary war (e.g. Baudrillard 1995; Der Derian 1998; Gray 2005). This literature alerts us to the crucial role of this cultural form, and the diverse modes of representation it offers of war and violence.

This article contributes to this burgeoning critical scholarship. It does so, specifically, by offering the first exploration of the importance of temporality within videogames centred around war, conflict, and militarism. The article's argument is twofold. First, we demonstrate that temporal representations, experiences and contexts are central to the ways in which war becomes meaningful across this genre of popular culture. Following Doty (1993) and Holland (2011) our emphasis here is on how arguments, assumptions and experiences of time are put to work in the construction of war's causes, conduct and consequences across this genre. The plot, settings, and mechanics that players of these games must navigate, we argue, emerge within, represent, reproduce, and contest specific temporalities that must be taken seriously. ${ }^{2}$

The article's second argument is that specific productions, representations and experiences of temporality are also vital for the political and aesthetic engagements with war they permit their consumers. For instance, videogames that are organised around rapid action mechanics or exceptionalist historical narratives use storylines and gameplay 
that can be used to make arguments about militarism's drivers and consequences. Others, in contrast, encourage a critical sensibility, for instance through 'counter-memorialising' (Ashley and Walker 1990, 410) or counterfactual readings of the past, or by ensuring that players linger at particularly unpleasant episodes of violence. To be clear, these productions and experiences do not (necessarily or directly) cause particular forms of player response to the challenges posed by a specific game. They do, however, make certain interpretations and actions appear more reasonable, logical, imperative or inevitable than others (Holland, 2011: 50-51). As the background which renders specific player decisions possible or reasonable (Doty 1993), different manifestations of time within military videogames therefore tell us much about the considerable heterogeneity, and critical potential, within this increasingly prominent form of global cultural politics.

To develop this argument, the article begins by reviewing contemporary literature on temporality and world politics. This literature, we argue, evidences a growing interest in rendering visible previously implicit assumptions, narratives, and experiences of temporality, and the social, political and discursive work they do in (re)producing global political dynamics such as war and conflict. In so doing, it has shown how specific temporal tropes - whether 'new wars', '9/11', 'the third world', or fears around 'digital Pearl Harbors' - are vital for the construction, organisation, and legitimation of, amongst other things, identity and violence.

A second section begins by differentiating three distinct instantiations of time that recur across this genre: (i) time as horizon, or historical backdrop, to videogame production and consumption; (ii) time as a dramatic setting to the plot of particular games; and, (iii) time experienced as duration during gameplay. These instantiations are then explored via a new typology which categorises videogames via their approach to contemporary warfare: (i) mainstream military shooters, which tend to place the player in the role of a member of the US military and place a premium on shooting to succeed; (ii) critical military shooters, which employ conventional shooter dynamics, but for critical intent; (iii) critical procedural military games, which use alternative gameplay mechanics but explicitly force a player away from combat, and (iv) civilian-centred military games, which place the player in the role of a civilian embroiled in a war beyond their control. 
This new typology, and the comparative exploration it facilitates, allows for analysis of the multiple normative and political potentialities of videogames - including their capacity to critique contemporary militarism. This is vital, because it extends the article's contribution beyond its immediate focus on imbrications of temporality, games and militarism. It does so by demonstrating the eclectic and diverse nature of this medium, helping to move debate on videogames and warfare beyond what we term 'mainstream military shooters' that have tended to capture the attention of analysts and researchers (for exceptions, see Robinson 2012, 2015; Young 2015; Ciută 2016; Schulzke 2017a, 2017b). In this article's third section we therefore analyse the various ways in which time functions as horizon, setting and duration across this typology, and the critical and political significance of the differences it uncovers. The article concludes with an overview of future research directions around temporality, popular culture, and militarism.

\section{Time, violence and global politics}

Any understanding of militarism is likely to prove only partial without some form of reflection on temporality. Three examples to demonstrate will suffice. First, justifications for war are, frequently, couched in temporal terms; whether looking forward to a (new) future - consider World War I as 'a war to end all wars' - or backward by reference to the righting of historical grievances. Second, war (like all social practices) is made up of, and made possible through, specific temporal rhythms, from the scheduling of military drills through to shifting combatant experiences of boredom and exhilaration (Basham 2015). Third, the ending of war and its posthumous existence in commemorative practices - from peace treaties to monuments, minutes of silence and beyond - relies upon the marking of time (differentiating an old time of war from a new time of non-war) as well as the endurance of collective calendars that are shared by, and arguably constitutive of, social groups whether nations, veterans or victims (Winter and Sivan 2000; Edkins 2003).

Given this significance, it is perhaps surprising that academic fields so dedicated to the study of war - such as International Relations - have been relatively slow to take temporality more seriously (Hom 2010, 1146; Solomon 2014, 671). Although the dominance of positivist epistemologies and structural ontologies, at least until recently, 
no doubt helps explain this neglect (Walker 1987, 66), things have, recently, begun to change. This is evident in studies unpacking the role of historical metaphors and arguments within elite security discourse - whether in relation to the endurance of World War II imaginaries (Noon 2004) or the use of other historical analogies in the George W. Bush administration's war on terror (Angstrom 2011). The allegorical role of specific events is a key focus of much of this work, for instance the resonance of Pearl Harbor in post-9/11 terrorism discourse (Jackson 2005), or fears of a 'digital Waterloo' in contemporary cybersecurity discourse (Stohl 2006). Related work extends these analyses by exploring how time is 'shaped' within global political narratives (e.g. on counterterrorism discourse (Jarvis 2009; Fisher 2013)), and by excavating arguments around temporal periodisations in tropes such as 'new terrorism' (Burnett and Whyte 2005) or 'new wars' (Newman 2004). Such work pulls attention to the ways in which particular pasts, presents and futures are selected and plotted into coherent stories or performances about international life, and the work these stories perform within efforts to render the international meaningful. Perhaps the best example, however, is in the debate on American exceptionalism. ${ }^{3}$ Some view this as a mythical, ahistorical and comparatively recent invention (Hughes 2015). Others instead employ it to periodise US foreign policy, distinguishing times of assertiveness characterised by national pride and moral superiority on the one hand. And, on the other, periods of, 'widespread self doubt and a sense of insecurity that give rise and direction to attempts at social purification when domestic problems and international uncertainties coincide' (Manheim, cited in McEvoyLevy 2001, 31).

These insights into time's plasticity - and the scope that this opens for military action or other forms of security politics - draw frequently upon now-canonical texts (itself a temporal claim!) within social theory, whether Maurice Halbwachs' (1992) work on social memory, or Walter Benjamin's differentiation between clock time and calendar time:

Benjamin associates clock time with the linear, deterministic, irreversible and indifferent time of historicism, in which political (even revolutionary) action is explained, in terms borrowed from Newtonian physics, as the product of material determination. Calendar time is different. Calendars require points of origin, and their recurrent dates are not indifferent points on the bland surface of a 
clock, but opportunities for remembrance and recreation that cut across and reinvent time (Hutchings 2008: 71-2).

Interdisciplinary engagements of this sort have enabled scholars to pay more attention to the significance of (often tacit) assumptions about time within established understandings of global politics (see also Lawson 2010; Yetiv 2011). Walker (1987), for instance, does this in relation to political realism: for him, a more complex terrain than often assumed precisely because of contrasting approaches to time within this 'school' and its foundational texts. Hom and Steele (2010) take a more panoramic approach, charting conceptions of 'cyclical time' and 'linear progressive time' within realist and liberal IR mainstreams, respectively. Kimberly Hutchings (2008) concentrates her attention instead on latent assumptions about linearity within this field's critical 'traditions'. The solace she finds in the revolutionary potential of feminist and postcolonial celebrations of global political 'heterotemporalities', here echoes Hom and Steele's endorsement of models of 'open time' and the emphasis upon novelty, contingency and unpredictability they associate with post-structural, pragmatist, and critical constructivist approaches. Related work, finally, focuses on the performance or enactment - rather than narration - of presents and futures in technologies, practices, or dramatic encounters emphasising risk. Drawing inspiration, again, from prominent social theorists (e.g. Butler 1997; Beck 2002), this literature charts how potential future scenarios are brought into being as real and meriting action through seemingly disconnected phenomena such as criminal trials (de Geode and de Graaf 2013) and security simulations (Aradau and van Munster 2012).

This brief review is intended to demonstrate two contemporary developments in the literature on temporality and global politics. First, is a growing attempt to render previously implicit assumptions, narratives and experiences of temporality as explicit as possible. And, second, is an effort to chart the significance thereof for many of this field's enduring concerns, including sovereignty (e.g. Jarvis 2009; Hom 2010), subjectivity (e.g. Solomon 2014), critique (e.g. Hutchings 2008), and danger (e.g. Aradau and van Munster 2012). This article offers something similar in the context of military videogames, arguing that specific (re)productions of time are vital for the construction, organisation and legitimisation of identity and violence within this medium. Beyond helping their 
consumers make sense of war, these (re)productions also variously facilitate or foreclose critical engagement thereof: shaping how their consumers make sense of war.

\section{Time to play! Military videogames and temporality}

In this section we draw on the critical insights of the above literature to explore three distinct instantiations of temporality within contemporary videogames. The first of these refers to the particular moment at which videogames are manufactured, marketed, distributed, sold, and consumed. This temporal horizon - or historical backdrop contributes, we argue, to the stories and experiences provided by particular videogames, albeit not homogeneously. Thus, videogames manufactured and played in a 'post-9/11' environment - even those focused on distant pasts or far-flung futures - are not unaffected by that environment. ${ }^{4}$ Second, time is also present, we suggest, as a dramatic setting in which videogames, their narratives and plots are situated. Such settings may involve past events (e.g. the Vietnam War); contemporary occurrences (e.g. the 9/11 wars); imagined future confrontations (e.g. following alien invasion), or some combination thereof (which may be arranged in a more, less or non- linear fashion within a specific title or series). Put otherwise, the strategies, battles, victims and violences of these games - as with the strategies, battles, victims and violences in other cultural forms - are located for their consumers within some time or times: past, present or future; real or fabricated. Third, temporality is also significant as duration in these games - as something which is experienced by an individual or community participating in their playing. This manifestation of time is particularly significant, we argue, for understanding the political and aesthetic sensibilities facilitated by such games. Thus, gameplay mechanics that work to accelerate or decelerate a player's decision-making, for instance, may encourage or discourage critical sensibilities vis-à-vis a game's violences.

This tripartite approach to temporality is applied, in the following, to an original typology of four types of military videogame: mainstream military shooters; critical military shooters; critical procedural military games, and civilian-centred military games. $^{5}$ Our argument is derived from analysis of twenty-seven games, with the discussion focused exclusively on the single player element of each. ${ }^{6}$ This provides for a descriptively rich investigation into key temporal dynamics within each of the four sub- 
genres, with examples to capture the importance of narrative, visuals, and gameplay therein. As noted above, the typology is also intended to broaden and deepen existing research which has tended narrowly to focus on the celebratory militarism of mainstream military shooters. Thus, we differentiate between games on their design and aesthetic, including differences in terms of their 'possibility space': referring to the actions a player can and cannot undertake during a game (Bogost 2007, 42-43). Our analysis builds from Bogost's work on 'persuasive games' which allow spaces for the exploration of rules through a process of experimentation (the possibility space) and can be used as metaphors to explore the rules that underpin society as a whole (procedurality), often in ways that are highly critical, yet expressive (procedural rhetoric). As Mary Flanagan (2009, 249) argues, '[g]ames are frameworks that designers can use to model the complexity of the problems that face the world and to make them easier for the players to comprehend. By creating a simulated environment, the player is able to step away and think critically about those problems'.

Whilst much of the existing literature focuses on games which are primarily concerned with offering critiques of society, our analysis argues that there is nothing intrinsic to this theory (and the potential of games) to suggest that they cannot also operate in a small 'c' conservative way. Persuasion could potentially yield a critical transformation but could serve equally well to consolidate the status quo or ameliorate against change. Our focus thus is sensitive to the reality view - as Schulzke (2017a, 6157) notes - that these games may be read in multiple ways (2017a, 615-7) and contain important ambiguities (Schulzke 2017b, 1). As Robinson (2015, 466-9) earlier emphasised, even apparently pro-war games can be seen as critical of war by actively exposing the existence of a military industrial complex at the heart of the US government.

\section{Mainstream Military Shooters}

Mainstream military shooter games such as the Call of Duty (2003-present), Battlefield (2002-present) and Medal of Honor (1999-2012) series are the dominant genre in the war videogame field, their releases frequently supported by significant marketing budgets and crucial to their publishers' commercial sustainability. The combined sales of such titles approximate 40-50 million copies per annum; which include combat games that situate 
the player as a serving member of the US (or an allied) military (e.g. Call of Duty series), and those which Stahl $(2006,118)$ terms 'insurgent hunting games' which locate the player as a member of a secret national security team charged with neutralising terrorist threats (e.g. Rainbow Six series).

These games are typically organised around a central narrative in which the player takes the role of a US or Western military operative whose individual agency - and heroism - is essential to military victory. The character is frequently engaged in statecentric war against uniformed soldiers from an enemy readily identified with a particular state, most frequently Russia (e.g. Call of Duty Modern Warfare series), China (e.g. Battlefield 4), North Korea (e.g. Homefront), or a generic Middle Eastern state (e.g. Battlefield 3). A blurring of 'new' and 'old' war tropes in these games emerges, however, with the widespread portrayal of one's enemies as 'extremists' - hence 'not real soldiers' - who are frequently 'collectivized and linguistically functionalized as "various terrorist groups", "militants" and "insurgents"' despite their military uniforms (Šisler 2008, 208). Combat in these games, moreover, has a theatrical, spectacular element (see McInnes 1999), placing modern hi-tech weaponry such as drones, remote and aerial weapons systems, tanks or attack helicopters in the hands of the player, confirming the allied forces' overwhelming technological superiority. In this sense, these games blur a comparatively ahistorical shaping of global politics as a site of perpetual danger (and, ultimately, war) that requires continuous and justified military action, on the one hand. With, on the other, a decidedly linear, and unashamedly progressive, conception of war's increasingly virtuous and virtual character (Der Derian 2009). Technological advances in these games ensure that the perpetrating of war by the West poses limited risk either to the self - the player's capacity to inflict collateral damage is often extremely limited - or to civilian populations, who are conspicuously absent from most mainstream military shooters.

These games are typically played from a first-person perspective, placing the player 'in the boots' of a soldier - almost without exception a male protagonist. Mainstream military games are typified as corridor-based, first-person shooters, offering a relatively linear experience that channels the player through a series of specific conflictbased scenarios. Progress in such games is therefore only possible through success in 
these battles; the space for negotiation with enemy aggressors is almost non-existent. In terms of time as duration, gameplay is therefore based on rapid and intense battlefield action, with a high premium placed on player dexterity. Time and speed are thereby 'collapsed', as these games present warfare as operating through the accelerated processes of what Crogan (2011) has termed 'gametime': 'an anticipatory impulse' (Stahl 2006, 119) and 'a temporal aesthetic that favours a discourse of constant action and the suppression of ethical reflection' (Stahl 2010, 100, paraphrasing Crogan). This serves to delimit the scope for a player's reflective or contemplative decision-making, serving - in a post-9/11 context that serves as their primary temporal horizon - to collapse 'the temporal space between real world events and the ability to "play" them' (Stahl 2006, 119). As Stahl $(2006,120)$ continues, in relation to the Iraq war of 2003: 'In the lead up to war, for example, the Bush administration pre-empted continued UN weapons inspections on the grounds that we were "running out of time"" (see also Glezos 2012). The possibility space is thus relatively narrow in such games, with this narrowing reflective of their post-9/11 backdrop which has been so frequently characterised by an 'urgency of emergency' (Salter 2011, 116) and the need for rapid decision-taking.

In terms of ethical motivation for the player's engagement in war, the majority of mainstream military shooters present this unambiguously, invoking an exceptionalist framing of American foreign policy. The player (almost always representing the USA) is typically attacked by an enemy and forced to respond (legitimately), either to a terrorist attack or a military invasion. These scenarios - demonstrative of US vulnerability to military violence in a post-9/11 climate - thus provide clear and unequivocal justification for military action to eradicate such threats (Robinson 2015, 459-462). This not only provides a point of temporal origin for conflict within these games, positioning the United States as the initial (therefore, innocent) victim and - in the process - camouflaging possible explanations for such originary violences. It also clearly demarcates the vulnerable self from its belligerent, barbaric others, guilty of unprovoked aggression lacking context or history.

Turning to time as a dramatic setting, in contrast to the other sub-genres considered below mainstream military shooters provide numerous commercially successful titles depicting multiple time periods including WWI (e.g. Battlefield 1 
(2016)), WWII (e.g. Call of Duty: WWII (2017); Call of Duty: World at War (2008)), the Cold War (e.g. Call of Duty: Black Ops (2010)), the 9/11 present (e.g. Medal of Honor (2010)), the post-9/11 present (e.g. Medal of Honor: Warfighter (2012)), as well as the near and distant future (e.g. Battlefield 4 (2013); Call of Duty: Black Ops 3 (2015)). The ease with which such games can move between settings reproduces the ahistorical framing of global politics as a site of perpetual danger and conflict noted above. Regardless of any particular game's specific temporal setting, war is (paradoxically) both unpredictable in that it cannot be averted, yet also inevitable: there would be no game without it, and no sequels to follow. Yet, within this broadly cyclical framing of an omnipresent (threat of) violence, the emphasis on causal events rather than processes within these games also tends to connect pasts and futures in relationships of radical disjuncture, characterised by intense moments of dramatic change rather than incremental transformations over time. Thus, as with Bush administration framings of the post-9/11 world as a time of new insecurity and 'known unknowns' (see Jarvis 2009), while a player might 'know' - or expect - future conflict to occur, the specific timing or modality of that conflict remains unforeseen.

What is crucial is that whether they are set in the past, the 9/11-scarred 'present', or the future, mainstream shooters offer procedural rhetoric (in Bogost's terms) with the potential to efface political and historical critique. For example, Call of Duty: Black Ops (2010) reconfigures historically problematic interventions in Cuba and Vietnam as necessary, justifiable responses to the existential threat posed by a global conspiracy amongst communist superpowers. The game's narrative simply establishes that such communist networks did exist, and that they posed a genuine threat to the USA. Call of Duty: Black Ops thus presents its players with a convincing, interactive rewriting of history in which the actions of the McCarthyite period, the US incursion into Vietnam, and the Bay of Pigs operation are all retrospectively justified. Put otherwise, such games offer a convincing counterfactual through which to make sense of, and evaluate, now past presents. Similar trends occur in Call of Duty: Black Ops II (2012), which contains a mission set in 1980s Afghanistan populated by a duplicitous Mujahedeen, and in Army of Two's (2008) post-9/11 depiction of WMD in both Iraq and Afghanistan in 2001. Such games make use of history's malleability to reproduce the past as a time of existential, 
permanent threat between the (good) USA and its (typically, non-Western) enemies. Their temporal aesthetic reinforces this Manichean simplicity, combining gameplay and stories that limit the ethical questions raised by US engagements in Cuba, Vietnam and beyond and erasing troublesome uncertainties or ambiguities from past foreign policy actions. $^{7}$

In offering our analysis it is important to emphasise that, perhaps surprisingly, a number of mainstream shooters do contain an important 'critical' undercurrent whereby a key cause of war is exposed as originating from the Military Industrial Complex. For example, Call of Duty: Modern Warfare 2 (2009), Call of Duty: Advanced Warfare (2014) and Army of Two (2008) all directly implicate the military and/or private security companies as direct sponsors of US enemies to protect their own interests - interests which are explicitly shown in game to be served by perpetual, techno-centric war (Robinson 2015, 466-9; Schulzke 2017b, 942-3). This criticality, however, is diminished, or - more strongly - effaced, by gameplay with its premium on rapid tempo, shoot and destroy mechanics.

\section{Critical Military Shooters}

Our second category of games which includes Blacksite: Area 51 (2007), Haze (2008) and Spec Ops: The Line (2012) utilises the gameplay mechanics of the mainstream titles discussed above, but for explicitly 'subversive' or 'disruptive' ends. Such games may provoke different affects (and indeed effects) in (and on) the player, their narrative and gameplay, in order to communicate war's ultimate destructiveness. Although commercially oriented (and supported by extensive marketing campaigns), these games have proven far less commercially successful than their mainstream competitors, limiting the examples available for discussion. ${ }^{8}$ Thus, where approximately 7-10 games are released annually conforming to the mainstream military shooter archetype - selling 40$50 \mathrm{~m}$ copies per annum - a critical military shooter tends to be released only once every 2-3 years, with typical unit sales of less than $1 \mathrm{~m}$.

As with mainstream shooters, critical military shooters place the player in the role of a serving member of the (typically US) military. The temporal experience of gameplay thus echoes the mainstream, first, with a premium on rapid action and limited scope for 
contemplative play, and second, by encouraging the player through a relatively linear journey of successive missions. Rather than depicting such actions as heroic, however, these games force confrontation with war's dehumanising effects on soldiers, including via appropriation of a shoot and destroy mechanic. In Spec Ops: The Line (SO:TL), for instance, this takes a figurative effect with the players' avatar (a soldier) frequently narratively and graphically darkened by war, allowing for the articulation of themes around PTSD (Payne 2014).

Both Haze and SO:TL expose the psychological damage of war upon soldiers. In $S O: T L$, the player's avatar (Captain Walker) becomes increasingly delusional, and the game's end reveals that the rogue enemy Walker had been pursuing - a US Colonel - has in fact been dead for weeks, with the taunting voices in Walker's head actually products of his traumatised and war-ravaged imagination. The unreliability of the player's avatar is a key theme, too, of Haze. Here, the game's narrative and gameplay involves future soldiers consuming a chemical substance (Nectar) which enhances combat focus and accuracy while masking the realities of their killings. As the character's Nectar unit malfunctions, the player is confronted with the horrors of their own actions, prompting the player to 'switch sides' and fight alongside erstwhile 'rebel enemies'. The player's complicity in war's horrors is further brought into question via confrontation with dramatic visual effects including increased shadows, destroyed clothes, and bodily distortions that accumulate during play. The disorienting impact of these effects is accentuated, importantly, by deliberate adjustments to time's durational character in these titles. Thus, while such games typically advance at considerable speed, the tempo of critical military shooters is often markedly reduced in those passages of play in which the player is forced to experience the impact of their own violences, and to confront the explicit and graphic depiction of dead bodies, including civilian casualties (e.g. Haze, September $12^{\text {th }}$ and SO:TL).

Turning to broader articulations of temporality, critical military shooters share with the mainstream a portrayal of perpetual danger: all of the above titles rely upon a shared sense of permanent insecurity. At the same time, their emphasis on the self's culpability in provoking and escalating war injects some element of (narrative) contingency into the (future) outcomes and scenarios of these games. Moreover, although 
the past as presented here serves once more as a lesson for the present or future, now the lesson's object is endogenous - and organised around the self's continuing failure to act with responsibility or restraint - not exogenous via reference to an anarchical world populated by antagonistic powers bringing insecurity to the self. At the same time, the linear sequencing that dictates gameplay within these titles means that progression throughout the game depends upon further violence and aggression. Indeed, the only way to prevent escalation of conflict here is for the player to put down their controller and refuse to fight. In this sense, critical military shooters offer a damning critique of the edifices of contemporary warfare and American exceptionalism. Importantly, though, America's unique status comes here not from its moral righteousness or unique vulnerability to unprovoked attack. Instead, it is a product of its matchless capacity to cause, escalate and wage war. Put otherwise, exceptionalism comes not from threats to the USA, but is instead seen in threats from the USA to the stability of the international order. These games - through their possibility space (gameplay) and procedural rhetoric (messages, visuals and narratives) - thus offer the potential to provoke a politically reflexive criticality in players who are forced to reflect through the narrative and gameplay of these games on the efficacies of past, present and future conflicts.

Given this, critical military shooters are somewhat more ambiguous in their depiction of allies and enemies than their mainstream counterparts. They often begin with an ostensibly clear player/enemy demarcation, which, as with mainstream military shooters, typically involves the player representing the US army. Yet, as the game unfolds, this demarcation often blurs. The player's own actions may, for instance, be revealed to be ethically problematic, as similarities between the player and their enemies become apparent (as in $S O: T L$ ); or the player may change allegiance (e.g. Haze) to fight former allies. Furthermore, these games are also more generally ambiguous in their portrayal of combatants; their structure more akin to a 'new wars' cast of allies and enemies including, for example, Private Military and Security Companies.

Concerning time as a setting, although critical military shooters share with the mainstream a depiction of 'war without end', this claim for permanent war is not made through the production of games representing multiple timeframes. In fact, they almost exclusively depict the 9/11-influenced present and/or the future. However, represented 
time is used in some cases allegorically or metaphorically: the 'present' of SO:TL, September $12^{\text {th }}$ and Blacksite: Area 51 and the future of Haze all serve to critique our past, present and anticipated future actions (see Davis 2010, 149-151). Moreover, while technology is also a crucial element of most critical military shooters, such games avoid the techno-fetishism of the mainstream by forcing confrontation with the violent consequences of high-tech weaponry, remote warfare and the like. These games often, therefore, demonstrate the scope of civilian casualties - most notably in the case of $S O: T L$, in which the player uses white phosphorous with devastating consequences. Here, although ostensibly attacking enemy soldiers, the targets are subsequently revealed to be civilians. Technologically mediated war thus does not mitigate risk. It is, in fact, directly implicated in the devastating loss of civilian life in contemporary warfare, and the ensuing erosion of human security.

\section{Critical Procedural Military Games}

Critical procedural military games such as the Metal Gear Solid (MGS) series (1987present) and Splinter Cell series (2002-present) are, like mainstream games, designed and released with commercial intent. Such games may have a significant marketing budget the $M G S$ series, in particular, has been hugely successful, selling 41.3 million copies worldwide - yet they utilise very different gameplay mechanics which place a premium on slower, more strategic forms of gameplay. ${ }^{9}$

Critical procedural military games generally place the player in the role of a lone special forces operative whose primary goal is to infiltrate an enemy facility before either rescuing captives or destroying a piece of hi-tech weaponry threatening global security. Future war is, therefore, preventable within these games and contingent upon a player's actions and agency, often assisted by non-playable allies and their intelligence, advice and assistance which may help in overcoming enemies, field survival, utilising weapons and so forth. The identity of belligerents, in these games, blurs 'old' and 'new' war paradigms. Enemies are predominantly soldiers representative of a clearly identifiable organisation (albeit one not necessarily mappable to a state), and clearly distinct from civilians who are seldom the victims of war. The motivation for enemy actions, however, maps more closely onto the new wars paradigm, being fought not for 'reasons of state or 
ideology, but for identity' (Kaldor, cited in Jarvis and Holland 2015, 131). Frequently, the 'enemy' turns out to be war itself, personified by the Military Industrial Complex, with the antagonists representing stakeholders in the state's militarisation. On the surface, therefore, there are parallels here with those mainstream shooters which expose a Military Industrial Complex as integral to the onset of contemporary war. Yet, whereas the actioncentric gameplay within mainstream military shooters trumps narrative story, critical procedural military games retain a powerful synergy between gameplay and narrative.

These games offer a very different experience of time's duration than the 'shooters' discussed above. The $M G S$ series, in particular, is renowned for its extensive use of narratives presented in cut-scenes designed to make both explicit and allegorical references to the dangers of war. The cut-scenes in $M G S 3$, for example, amount to roughly 5 hours in length out of a total playtime of approximately 16 hours. In MGS4 they account for approximately 8 hours of 20 hours total playtime. Critical procedural military games, like all of the games discussed in this article, thus both communicate allegorically but are also a contributor to allegorical forms of political communication about the causes of war. The criticality served by this manipulation of time's passing for players is complemented here, however, by more explicit critique of the growth of technologically-mediated war. Games within the $M G S$ series, for example, frequently expose the dangers of technologically augmented cyber soldiers, mechanised remote warfighting, and weapons of mass destruction (WMD). Thus, unlike critical military shooters, the player seldom makes use of hi-tech weaponry themselves, with their technology restricted to items such as binoculars or scanning equipment designed to aid concealment and stealth, rather than weaponised for lethal purpose.

Like both critical and mainstream military shooters, though, critical procedural games re-affirm the geopolitical condition as a period of enduring insecurity. Concerning time as a dramatic setting, the majority of these titles are situated in a 9/11-influenced 'near present', with all of the Splinter Cell games and both $M G S$ and MGS2 covering events framed to the player as happening 'now' or in the 'near future'. In all cases, these games use extensive allegorical reference points to illustrate that the motivations of those seeking absolute power and the dangers of militarisation are permanent, inescapable features of (global) political life. 
This is particularly evident in the four $M G S$ games released after 9/11, each of which explicitly vacated the $9 / 11$ present for their setting - with three games set during the Cold War (MGS3 (1963), MGS5: Ground Zeroes (1975), MGS5: Phantom Pain (1984)) and one set in the future (MGS4 set in 2014; released in 2008) - while still resonating strongly with that present. For example, MGS5: Ground Zeroes places the player as a stealth operative (Big Boss, aka Snake) attempting to rescue two prisoners from a fictional American 'Blacksite' in Cuba (Camp Omega), with the gameworld providing an open world realisation of the whole island complex. The game's critical purchase is shown in its narrative, which offers a critique of the internment of captives in the contemporary war on terror. And, while set in 1975, the game's setting - perhaps intentionally - evokes powerful allegorical feelings around the US military prison at Guantanamo Bay - itself, of course, in Cuba.

In comparison to the other categories of game explored above, critical procedural military games are of additional interest to this article for a particularly pronounced engagement with memory and forgetting. Unlike mainstream military shooters which although often set in the past - typically foreclose discussion of previous errors and failings, games such as $M G S$ coalesce pasts, presents and futures as sources of permanent regret. In all of these games the lead protagonist Snake (in his various incarnations) ruminates explicitly on his own history and that of his former allies (now corrupted by power) to consider how his current actions may bring closure to his martial past through avoiding present conflict. Memory also features in these games, moreover, through their non-linear release - MGS and MGS2 were set in the present; MGS3 in the past; MGS4 in the future, and the two MGS5 games both set in the past. The player is thus able to remember what their in-game avatar cannot, and is also able to 'know' the future which Snake cannot.

Where critical procedural military games perhaps differ most from either mainstream or critical military shooters is in their pattern of gameplay, which places a high premium on stealth rather than shooting. The player is seldom engaged in gunplay: when they are, they are rapidly outnumbered and killed. As such, the player is actively encouraged to avoid conflict. Gameplay, rather than being rapid and action-centred, is thus contemplative and reflective - the tempo in critical procedural military games is far 
slower and the choices available to the player are frequently wide. This can be shown both in the variety of ways in which the player can navigate the game space, and in the scope of options open to the player to overcome set objectives (vis-a-vis linear or 'corridor-based' titles). In consequence, the possibility space of such games is frequently wider than that of mainstream military shooters, notwithstanding the frequent scripting out of the capacity to play as a shooter. The player's character, moreover, is frequently represented in the third person, making the game 'easier' by broadening the field of vision and thereby aiding stealth-oriented gameplay. Crucially, playing in the third person also affirms a different kind of affinity between player and character compared to a firstperson shooter - rather than placing the player in the 'boots of the soldier' - the norm in a mainstream military shooter - the player here plays out the protagonist's story.

\section{Civilian-centred military games}

This genre is the most recent of our four, and exemplified by two recent releases: Sunset (2015) and This War of Mine (TWOM) (2014). ${ }^{10}$ While these games have relatively modest sales despite commercial intent $(18,600$ and $1.8 \mathrm{~m}$ respectively - the former being declared a critical and commercial failure; the latter a critical and commercial success) both offer an explicitly artistic and critical intervention into contemporary militarism. ${ }^{11}$ Each provides important rejoinder to the predominant focus on soldiers' stories within war videogames, casting the player as a civilian forced to navigate a warzone not of their making. This impression of perpetual insecurity feeds into a similarly ahistorical - and similarly realist - impression in these games wherein suspicion and self-interest are abandoned only at considerable risk to the player. Allies, such as they exist, are limited to other civilians who may aid the player. Yet the perils of humanitarian catastrophe mean that - in TWOM in particular - war-generated desperation will often lead to conflict between civilians, rendering fellow 'victims' potential future enemies. In focusing on civilian casualties, they therefore question the productivity of war itself, giving voice to protagonists overwhelmingly absent in other war-based videogames.

Both Sunset and TWOM challenge the player - situated here as a civilian - with survival in a contemporary war-scape. In terms of temporality, this leads to an emphasis on more cerebral patterns of play, with a premium placed on contemplative and reflective 
activity. Whilst Sunset is exclusively slow-paced, in TWOM rapid action is most closely associated with periods of fear and panic and is more likely to result in death than the survival promoted in mainstream and critical military shooters. In contrast to the games considered above, there is also no comparable celebration of technology here: players in TWOM are tasked with scavenging to survive, and technology, such as it is usable by the player, is rudimentary. Outside of the player's influence, however, the consequences of technologically facilitated war are seen and experienced through the ravaging of the physical environment the player attempts to navigate. Here war's technological advancement is not, therefore, accompanied by a similarly linear sense of normative progress.

Within civilian-centred military games conflict is explicitly to be avoided, as with the critical procedural military games. However, where critical procedural games afford the player latitude to respond with violence where necessary, in Sunset no comparable capacity exists as violence is scripted out of the game: the player is cast as a civilian who observes war's destructive force through the windows of a penthouse in which she is trapped in her role as a cleaner. TWOM, in contrast, explicitly exposes the considerable asymmetry in capacities for violence between civilians and combatants in contemporary war zones. In this sense, therefore, the possibility space of these games is relatively narrow. Where Sunset prevents violence through its gameplay, TWOM forces the player into desperate measures to ensure their own survival. Yet $T W O M$ strongly dissuades killing, as if the player engages in violence it is likely to result in death to the player or other civilians. Even when conflict is avoided, stealing - which is essential to survival in TWOM - has the unwelcome result of depression for one's character who is forced to reflect on the costs of their actions.

In terms of their temporal setting, whilst both of these games are set in the past, they encourage reflection on the present and future. Sunset is set in 1972-3 in a fictional African country (Anchuria), whereas TWOM is set in an inferred past in an unspecified war-torn state. The latter is explicitly described by the developer as a metaphor for the Sarajevo siege (1992-6) but may be as easily read as representative of the siege in Aleppo, for instance. These games, like critical procedural military games, can thus be seen both as offering a message that is steeped in allegory and also as contributing (as popular 
cultural artefacts) to an age in which communication about war and conflict is increasingly framed figuratively.

Finally, perhaps uniquely, the implications of these games in terms of temporal considerations of American exceptionalism are ambiguous. Whilst critical of war (which may infer a critique of American exceptionalism), they seem to suggest a need for greater levels of international intervention to avert war and protect civilians. In $T W O M$, for example, conflict is ultimately brought to an end through the intervention of the United Nations, whereas in Sunset, US intervention is crucial to ending the conflict both through the player's actions as a trapped US citizen (Andrea) and the actions of Andrea's brother: a US citizen and leader of the resistance. In both games, therefore, a case to uphold American exceptionalist foreign policy as a force for benign good and moral purity is arguably offered - it is only through external Western intervention that civilians can be protected against otherwise certain death.

\section{Playing with time}

As the above suggests, military videogames are both located in, and constitutive of, multiple and overlapping temporal conditions and experiences. To return to the three roles of temporality introduced above, all of the games discussed here may be approached - as may all popular culture - as a product of a particular temporal horizon. Interestingly given the heterogeneous normative, political and aesthetic experiences on offer - that horizon emerges as a relatively coherent one across our sub-genres: it is one dominated by the immediate and then receding shadow of the 11 September 2001 attacks and subsequent '9/11 wars'. ${ }^{12}$ Thus, on the one hand, these videogames are marked by engagement - both sympathetic and critical - with a range of particularly prominent themes in post-9/11 political discourse. Tropes around American exceptionalism, American innocence, and American insecurity, for instance, have been a mainstay of political and media debate in this period, and it is - therefore - unsurprising to see their presence so starkly in this genre. At the same time, these games offer direct engagement with developments in contemporary warfare - from the emergence of high-tech weaponry such as drones, to the growing recognition of the realities of PTSD - allowing, in some examples, creative engagement with very contemporary events, fears and imaginaries 
including around WMD programmes in Iraq and Afghanistan. Yet, it is also important to note that this post-9/11 horizon has not been entirely unchanging, and the most critical and disruptive military videogames in our analysis - civilian-centred military games are those which emerged most recently, some thirteen to fourteen years after the $9 / 11$ attacks, and five years after the end of President Bush's second term of office.

There is nothing unique to videogames in this sense: popular culture is always influenced, at least, by the historical circumstances of its production, which may include prevailing ideas, available technologies, aesthetic tastes, and so forth. As Michael Shapiro (2009, 48-9) has observed, the time (actual date) at which we experience a particular cultural form (a game or a film) and the time (or date) at which the form was produced matter. Thus, where films engaging with war date back to the pre-WWII period, games as a medium only date to the late 1970s. Indeed, it was arguably not until the 2000s, with the launch of Xbox 360, PS3 and advances in PC technology, that games had the technical and storage capacity to offer detailed, story-driven narrative engagements with visceral combat. The implications of this are profound, with games centred on pre-9/11 conflicts such as the Vietnam War all produced (and hence played) after the 9/11 attacks. The canon of - often critical - films on the Vietnam War, in contrast, was overwhelmingly produced during the 1970s and 1980s in a period of US national self-reflection in relation to that war.

The second significant manifestation of temporality concerned the dramatic setting(s) in which games and their narratives are situated. As we have seen, military videogames make use of - and (re)produce - diverse representations of pasts, presents and futures, drawing on imaginary future confrontations as well as 'real' historical events, especially from the twentieth century's great geopolitical conflicts. Importantly, mainstream military shooters are most capable of moving between multiple representations of past, present and future - often within single series of games - while critical games tend to use their temporal setting allegorically, enabling insight into present and future confrontations. The former's manoeuvrability, we argued, contributed to a cyclical shaping of temporality in which the transplanting of similar plots and events serves to construct global politics as a dynamic of return and recurrence. Thematic continuities within (and in some instances beyond) this sub-genre, moreover - US 
vulnerability to external threat; American exceptionalism; the bellicosity of non-Western others (whether Russian; Chinese; North Koreans, or non-Western terrorists) - contribute to a sense of historical determinism. As, interestingly, does the organisation of gameplay within these titles in which corridor-based sequences of events propel the player along a seemingly linear path between past, present and future. The narrative and aesthetic structure of other games, in contrast, offers a far greater role for contingency and the agency of players, dramatically loosening the connections between storied and played pasts, presents and futures.

Despite their potential for creative engagement with past, present and future conflicts, mainstream military videogames (notwithstanding the minority of games which expose a Military Industrial Complex behind a state's war mobilisations) on balance close space for critical reflection on the efficacies and ethics of warfare through gameplay, whereas critical games (through a synergy of narrative and gameplay) typically serve to open such space. In the case of mainstream shooters, neither Vietnam nor contemporary wars in Afghanistan or Iraq are positioned as events meriting regret. Indeed, military action is, almost universally, presented as a justifiable and necessary response to (typically, American) insecurity. Critical games, in contrast, suggest that peace is the norm, that enemies are actually frequently present within the very fabric of the US war machine (the Military Industrial Complex), and that American exceptionalism invokes ethically problematic foreign policy.

Third, thinking of time as duration in these games, mainstream and critical games facilitate sharply contrasting encounters with the experience of time for their players. If, as argued above, mainstream shooters close down space for critical reflection by virtue of their storying of particular events, their meaning and sequencing, this is compounded by the accelerated processes characteristic of 'gametime' in this sub-genre. The procedural rhetoric which emphasises unreflective action within the 'shoot first, ask questions later' dynamic typical of these games leaves scant opportunity for ethical or political questioning within these games about their ostensible objects (war in the past, present or future) or, indeed, for considering the persuasive potential of these games (in Bogost's terms). War, here, is an exciting encounter characterised by urgency, danger, and bloodshed. This, again, contrasts strikingly with critical military games which either 
use speed to expose the perils of rapid decision taking or employ more cerebral playstyles to open space for critical reflection.

\section{Conclusion}

This article has explored a number of intersections between military videogames and temporality. Two overarching arguments were made. First, that time plays at least three roles in this genre - acting as horizon, setting and experienced duration - all of which are central to the ways in which war is made meaningful therein. As demonstrated above, such games: imagine past, present and future events in specific ways; connect past, present and future events according to diverse patterns; accelerate or decelerate experiences of war to either facilitate or foreclose critical reflection; and, are situated against a very specific 'real world' backdrop dominated by a growing distance from the events of 11 September 2001. The article's second argument was that these productions, representations and experiences of temporality are vital for the political and aesthetic engagements with war available to videogame consumers. Military videogames, as we have seen, both: celebrate and mourn militarism; force and prevent player engagement in violence; and, encourage and discourage reflection on the implications of the violences of self and other. Thus, variation in the way temporality is put to work in these games is key for the critical potential - or lack thereof - within this genre, which emerges as more heterogeneous than often assumed.

As a first effort to analyse imbrications of militarism and temporality within videogames, this analysis points to a number of potentially productive directions for future research. In the first instance, there is obvious scope for far more explicit comparative analysis between representations of temporality in military videogames and other war-oriented forms of popular culture, including film, television shows, theatre, or literature. Such analysis would shed further light on the distinctiveness (or otherwise) of this medium, and of the significance of temporal horizons, in particular, for dynamics of cultural production and consumption. Second, there is possibility for further work explicitly engaging with military videogames portraying more speculative - temporally distant - scenarios such as where Earth or a human colony is under siege from alien 
invasion (e.g. Halo 2, Halo 3; the Gears of War and Killzone series). These future-focused games offer distinct articulations of identity to many of those considered above.

Third, portrayals of present and/or future war also suggest scope for greater reflection on the recreational representation of advanced military weaponry such as UAVs and the implications of this. A fourth - and perhaps most pressing - line of enquiry would be to focus on audiences, and the implications for players of the diverse ways in which games engage with temporality and war. Such work could build from existing work around the 'sociology of gaming'. Galloway $(2006,78-84)$ on military videogames, and player feelings or positionalities offers a useful starting point (see also Crane-Seeber, 2016, 49-50). Future research could also explore player understandings and experiences of temporality in the narratives and actions presented by videogames, and the extent to which these are internalised, interrupted or resisted in the playing of these games and beyond. How, for instance, are the multifaceted forms of temporality identified above brought to bear in the decoding of other violences encountered on news media and in film? And how do temporal claims, for example in terms of representation of past conflict or the use of hi-tech weaponry, figure in the discussion of videogames in dedicated forums online and offline? Such questions are some way beyond this article which offers a first attempt to explore intersections between temporality, militarism and videogames.

\section{References}

Activision. 2016. Activision Blizzard announces fourth quarter and full year 2015 financial results. Activision Press Release, February $11^{\text {th }}$ 2016: http://investor.activision.com/releasedetail.cfm?ReleaseID $=954612$

Angstrom, J. 2011. Mapping the Competing Historical Analogies of the War on Terrorism. International Relations 25, no. 2: 224-42.

Aradau, C. and van Munster, R. 2012. The Time/Space of Preparedness: Anticipating the "Next Terrorist Attack". Space and Culture 15, no. 2: 98-109. 
Ashley, R.K. and Walker, R.B., 1990. Conclusion: Reading dissidence/writing the discipline: Crisis and the question of sovereignty in international studies. International Studies Quarterly 34, no. 3: 367-416.

Basham, V. 2015. Waiting for war: Soldiering, temporality and the gendered politics of boredom and joy in military spaces. In Emotions, Politics and War, eds. L. Ahall and T. Gregory, 128-140. Abingdon: Routledge, pp. 128-140.

Baudrillard, J. 1995. The Gulf War Did Not Take Place. Sydney: Power Publications.

Beck, U. 2002. The Terrorist Threat: World Risk Society Revisited. Theory, Culture \& Society 19, no. 4: 39-55

Bogost, I. 2007. Persuasive Games: The Expressive Power of Videogames. Cambridge: MA: MIT Press.

Burnett, J. and Whyte, D. 2005. Embedded Expertise and the New Terrorism', Journal for Crime, Conflict and the Media 1, no. 4: 1-18.

Butler, J. 1997. Excitable Speech: A Politics of the Performative. Abingdon: Routledge.

Ciută, F. 2016. Call of Duty: Playing Video Games with IR. Millennium: Journal of International Studies 44, no. 2: 197-215.

Crane-Seeber, J.P. 2016. Sexy Warriors: The Politics and Pleasures of Submission to the State. Critical Military Studies, 2, no.1-2: 41-55.

Crogan, P. 2011.Gameplay Mode: War, Simulation, and Technoculture. Minneapolis, MN: University of Minnesota Press.

Davis, T.C. 2010. Performative Time. In Representing the Past: Essays in Performance and Historiography, eds. Charlotte Canning and Thomas Postlewait, 142-167. Iowa City, IA: Iowa University Press.

Doty, R. 1993. Foreign Policy as a Social Construction. International Studies Quarterly 27, no. 3: 297-320.

de Goede M. and de Graaf, B. 2013. Sentencing Risk: Temporality and Precaution in Terrorism Trials. International Political Sociology 7, no. 3: 313-331.

Der Derian, J. 1998. All But War is Simulation. In Rethinking Geopolitics, eds. Gearóid Ó Tuathail and Simon Dalby, 261-73. London: Routledge.

Edkins, J. 2003. Trauma and the Memory of Politics. Cambridge: Cambridge University Press. 
Fisher, K.M. 2013. Exploring the Temporality in/of British Counterterrorism Law and Law making. Critical Studies on Terrorism 6, no. 1: 50-72.

Flanagan, M. 2009. Critical Play: Radical Game Design. Cambridge MA: MIT Press.

Galloway, A.R. 2006. Gaming: Essays on Algorithmic Culture. Minneapolis: University of Minnesota Press.

Glezos, S. 2012. The Politics of Speed: Capitalism, the State and War in an Accelerating World. Abingdon: Routledge.

Gray, C.H. 2005. Peace, War, and Computers. Routledge: London.

Höglund, J. 2008. Electronic Empire: Orientalism Revisited in the Military Shooter. Game Studies 8, no. 1.

Holland, J. 2011. Foreign Policy and Political Possibility. European Journal of International Relations 19, no. 1: 49-68.

Holsti, K.J. 2011. Exceptionalism in American Foreign Policy: Is it Exceptional? European Journal of International Relations 17, no. 3: 381-404.

Hom, A. 2010. Hegemonic Metronome: The Ascendancy of Western Standard Time. Review of International Studies 36, no. 4: 1145-70.

Hom, A. and Steele, B.J. 2010. Open Horizons: The Temporal Visions of Reflexive Realism. International Studies Review 12, no. 2: 271-300.

Huntemann, N.B. and Payne, M.T. eds. 2009. Joystick Soldiers: The Politics of Play in Military Video Games. London: Routledge.

Hutchings, K. 2008. Happy Anniversary! Time and Critique in International Relations Theory. Review of International Studies 33, no. S1: 71-89.

Jackson, R. 2005. Writing the War on Terrorism: Language, Politics and CounterTerrorism. Manchester: Manchester University Press.

Jarvis, L. 2009. Times of Terror: Discourse, Temporality and the War on Terror Basingstoke: Palgrave.

Jarvis, L. and Holland, J. 2015. Security: A Critical Introduction. Basingstoke: Palgrave. Lawson, G. 2010. The Eternal Divide? History and International Relations. European Journal of International Relations 18, no. 2: 203-226

McEvoy-Levy, S. 2001. American Exceptionalism and US Foreign Policy: Public Diplomacy and the End of the Cold War. Basingstoke: Palgrave. 
McInnes, C. 1999. Spectator Sport Warfare. Contemporary Security Policy 20, no. 3: $142-65$.

Newman, E. 2004. The "New Wars" Debate: A Historical Perspective is Needed. Security Dialogue 35, no. 2: 173-89.

Noon, D.H. 2004. Operation Enduring Analogy: World War II, the War on Terror, and the Uses of Historical Memory. Rhetoric \& Public Affairs 7, no. 3: 339-64.

Payne, M.T. 2014. War Bytes: The Critique of Militainment in Spec Ops: The Line. Critical Studies in Media Communication 31, no. 4: 265-82.

Power, M. 2007. Digitized Virtuosity: Video War Games and Post-9/11 CyberDeterrence. Security Dialogue 38, no. 2: 271-88.

Robinson, N. 2012. Videogames, Persuasion and the War on Terror: Escaping or Embedding the Military-Entertainment Complex? Political Studies 60, no. 3: 504-22.

Robinson, N. 2015. Have You Won the War on Terror? Military Videogames and the State of American Exceptionalism. Millennium: Journal of International Studies 43, no. 2: 450-70;

Salter, M.B. 2011. When Securitization Fails: The Hard Case of Counter-Terrorism Programs. In Securitization Theory: How Security Problems Emerge and Dissolve, ed. T. Balzacq, 116-131 Abingdon: Routledge..

Schulzke, M. 2013. The Virtual War on Terror: Counterterrorism Narratives in Video Games. New Political Science 35, no. 4: 586-603.

Schulzke, M. 2017a. Military Videogames and the Future of Ideological Warfare. British Journal of Politics and International Relations 19, no. 3: 609-26.

Schulzke, M. 2017b. Interpreting and Reinterpreting the Political Significance of Popular Media: The Importance of Seeing from a Range of Perspectives. Political Studies 65, no. 4: 930-46.

Shapiro, M.J. 2009. Cinematic Geopolitics. London: Routledge.

Šisler, V. 2008. Digital Arabs: Representation in Video Games', European Journal of Cultural Studies 11, no. 2: 203 - 20. 
Solomon, T. 2014. Time and Subjectivity in World Politics. International Studies

Quarterly 58, no. 4: 671-81.

Stahl, R. 2006. Have you Played the War on Terror? Critical Studies in Media

Communication 23, no. 2: 112-30.

Stahl, R. 2010. Militainment, Inc: War, Media, and Popular Culture. Abingdon:

Routledge.

Stohl, M. 2006. Cyber Terrorism: A Clear and Present Danger, The Sum of All Fears, Breaking Point or Patriot Games? Crime, Law and Social Change 46, no. 4-5: 22338.

Walker, R.B.J. 1987. Realism, Change and International Political Theory. International Studies Quarterly 31, no. 1: 65-86.

Winter, J. and E. Sivan, eds. 2000. War and remembrance in the twentieth century. Cambridge: Cambridge University Press.

Yetiv, S. 2011. History, International Relations and Integrated Approaches: Thinking about Greater Interdisciplinarity. International Studies Perspectives 12, no. 2: 94118.

Young, R. 2015. Going Fifth Freedom: Fighting the War on Terror in the Splinter Cell: Blacklist Video Game. Critical Studies on Terrorism 8, no. 1: 147-62.

\footnotetext{
${ }^{1}$ See http://www.army.mod.uk/startthinkingsoldier. Last accessed 3 May 2018.

${ }^{2}$ Our thanks to one of the anonymous reviewers for encouraging us to clarify our approach here.

${ }^{3}$ A similar argument may equally be made in relation to debate around American decline.

${ }^{4}$ For a recent critical engagement with challenges posed by temporal periodisations such as pre- and post9/11, see Harmonie Toros, '9/11 is Alive and Well: Or How Critical Terrorism Studies has Sustained the 9/11 Narrative', Critical Studies on Terrorism 10, no. 2 (2017): 203-219.

${ }^{5}$ In setting out this typology, we are not claiming that others have not also sought to expose the critical intent within videogames (see, for example, Robinson 2012; and Schulzke 2017b). Instead, we offer a uniquely comprehensive framework, which explores military games in their totality.

${ }^{6}$ Whilst many of the mainstream games we analyse are made in North America, it is important to emphasise that a number of the critical games that we consider below are made elsewhere (e.g. Spec Ops: The Line is made by a German developer; This War of Mine by a Polish developer; Sunset by a Belgian art collective; and the Metal Gear Solid series are made by a Japanese developer).

${ }^{7}$ In making this claim we do not deny that players retain significant potential to question and critique such messages. Instead our emphasis is on the narratives, settings and gameplay within such games.

${ }^{8}$ One important exception is the game September $12^{\text {th }}$ (2003) a non-commercial, activist produced game which similarly seeks to question the efficacies of shooting and destroying both for the player and by implication of the US war on terror.

${ }^{9}$ Data on MGS series from vgchartz.com as of April 2017. Splinter Cell Conviction (2010) is perhaps the outlier here with a more action-centric pattern of play.
} 
${ }^{10}$ Both Home Behind (2016) and Valiant Hearts (2014) also feature civilians as the main protagonists but they feature a more action-centric pattern of play and are thus very different in feel.

${ }^{11}$ Sales data for both of these titles are conservative estimates derived from steamspy.com which captures PC-based download figures activated on Steam. TWOM, in particular, was distributed as a 'free title' on PlayStation Network (February 2017) and so will thus have higher user figures than estimated here.

${ }^{12}$ As Stahl (2006, 118) argues: 'September 11, 2001 and the ensuing wars in Afghanistan and Iraq ushered in a boom in sales of war-themed video games for the commercial market'. 